\title{
POLITICIZING THE NEW NORMAL: SUBPOLITICAL RISK SOCIETY OR POST-POLITICAL SOCIETY AT RISK?
}

\author{
Jasmin Hasanović 27 \\ Faculty for Political Sciences, University of Sarajevo
}

\begin{abstract}
Since the beginning of the coronavirus pandemic, along with the longings for a return to "normal state", statements that nothing will be the same afterwards could also be heard. However, the real task remains in deconstructing the relationship between the pre-pandemic normality and the political consequences that coronavirus has shed light on. Hence, the idea of a global risk society, developed by sociologist Ulrich Beck and Anthony Giddens, could easily be recalled within those circumstances. Questioning the role of politics and political science while assuming that we live in a post-industrial age, the central idea presupposes that politics is displaced from the traditional areas of big, ideological questions. In other words, in the age of Anthropocene marked as reflexive modernization, it is being considered that politics is merely taking place as subpolitics, dealing with individual things considering small, everyday life politics. Deprived of big questions, it rather anticipates manmade risks as the consequences of modernization and achievements of the changed nature related to production and distribution in capitalist societies. Though, this paper aims to see how the global state of emergency - as a state of exception - shook such ideas, illuminating their hidden ideological charge with the goal to normalize the relations of power and domination within society. In this regard, the paper also seeks to contribute to the discussion of the importance of social and political crises and transformations, and to affirm a critical concept of theoretical practice.
\end{abstract}

Keywords: COVID-19 pandemic, politics and the political, post-politics, risk society, subpolitics.

\section{Starting points}

Two years after the outbreak of the COVID-19 pandemics, several new phrases became common sense, even clichés in our vocabulary, everyday jargon, scientific work, communication, and mindset in general. We are starting our e-mails with hopes that they will find our correspondents safe, well and healthy, as we are talking about the "new circumstances" under the "new normal". Longings for returning to the previous "normal" and the statements that "nothing will be the same again" could be heard soon after. However, it did not take long since the global lockdown in mid-2020 to understand how the so-called "new normality" visibly does not sharply dissect a state to "before" and "after". Instead, it is produced simultaneously. Perhaps the genuine inquiry should be to deconstruct the

${ }^{27}$ Contact address: jasmin.hasanovic@fpn.unsa.ba. 
relationship between pre-pandemic normality and the still ongoing political consequences that the coronavirus pandemic has shed light on.

It is likely that many of us recently came across studies or articles on how billionaires got richer during pandemics, more precisely - even $54 \%$ according to a recent analysis by the Washington-based Institute for Policy Studies - IPS (Picchi, 2021). According to Forbes' data, in the United States, nearly 500 people became billionaires (Peterson-Withorn, 2021), while about 650 billionaires increased their net worth by more than $\$ 1$ trillion (Beer, 2021) during the pandemic. On the other side, US president Joe Biden remarked in his address to Congress in April 2021 that "twenty million Americans lost their job in the pandemic" (The White House, 2021). So, how could this be even possible if we all were, as some were shouting, in the same boat? Making jobs even more uncertain, the even greater precarization of labor and market logic under the state of the new normality illuminate the general class antagonism and show how the phenomenon of the new normality needs to be approached in a much deeper and systematical sense. ${ }^{28}$

Understood as "normality", the logic of the "previous state" is being inscribed into "new state" as the state of the "new normality". In linking the pandemic's absence of normality with a state of uncertainty, an initial shock in which we did not know what to expect, Samir Foric underlines how the absence of generalized social expectations regulating these behaviors is overcome by their legal codification. As a deviation within society, abnormality - the absence of normality - becomes replaced by new normality when it is transformed into "legal norms that prescribe clear expectations of our individual behaviors", so that our gradual habituation to them, as a reflection of a broader process of adjustment will eliminate the reasons for the state of concern - in which "the new normality is simply transformed into - normality" (Forić, 2020).

Not only left-wing theorists, especially those of Marxist provenance (aside from how controversial this phrase may be) would agree that crises are immanent to the capitalist mode of reproduction, but this is also what its proponents like Milton Friedman (2002: xiv) remind us of in situations like this. Without going further into examples, whether it is Bush's "war on terror", the global economic crisis of 2008 or natural disasters, capitalism seems to seek to exploit the crises for its benefit. However, like in 2008, the pandemic trivialized the myth of a self-regulating market while surviving on public money. It also called market determinism into question the moment people started buying what they needed..$^{29} \mathrm{On}$ the other side, the

${ }^{28}$ Taking an example of Bosnia and Herzegovina where between 28-30 000 people lost their jobs only in the Federation of Bosnia and Herzegovina in the first half of 2020 which Government had to allocate 500 million KM (cca. 250 million euros) for implementing the proposal of the Law on Mitigation of Negative Economic Consequences of COVID-19, the so-called "Corona Law", while at the same time, there are 12,89 billion KM (cca. 6,6 billion euros) of savings in BiH commercial banks (CBBH, 2019) showing that a wealthy minority holds a significant share of the money in their hands, that is, on their bank accounts.

29 The state of isolation has left us to use virtual spaces and social networks as the only free, clean spaces (from infection). Thus, the work itself had to adapt to the new circumstances, creating difficulties to those sectors depending on manual work (but not only to them), which is why many people lost their jobs. Those forms of work that could were adopted and moved to virtual spaces, further strengthening immaterial forms of work as the algorithms of new subordination (Barlett, 2018). Economic analysts, both in the world and in the region, immediately started launching positive campaigns in favour of the 
predominance of a microscopic, invisible virus of (un)known origin (Boyle 2020) over the modern, technologically superior humanity could - at least briefly - recall the idea of a global "risk society" developed by the German sociologist Ulrich Beck (1992; 2009) and British sociologist Anthony Giddens (2006), assuming that we live in the age of Anthropocene marked as reflexive modernization, anticipating man-made risk as the consequences of modernization and its achievements - it defines what Beck considers the second modern(ity).

At the same time, it seems how the relevance of politics disappears. Important policy decisions over our everyday lives are left to unelected experts, lobby groups, technocrats, and global corporations. Politics has been replaced by the "governing of technology" instead being the "technique of governing". However, we are also witnessing the renewed interest in authoritarian, sovereigntist tendencies of the states - not only on the "undemocratic" and "illiberal" Rest - but also within the very core of West's liberal democracies. The trend of democratic backsliding is not embraced only by right-wing populists but also by the protectors of the liberal status quo - it is even more illuminated in encouraging the rise of digital securitization and surveillance capitalism, a coin being recently popularized by Shoshana Zuboff's (2019) book - all in the name of protection against the risk of coronavirus. ${ }^{30}$

\section{Depolitizing the political}

For Ulrich Beck, the changes brought to us by the industrial revolution introduce us to the post-industrial world, being the second phase of modernity - the second modernity. It is a society within which risks, as the side-effects that accompany new forms of production occur. In risk societies:

[t]he consequences and successes of modernization become an issue with the speed and radicality of processes of modernization. A new dimension of risk emerges because the conditions for calculating and institutionally processing it break down in part (...) the world can no longer control the dangers produced by modernity (...) not because of its omissions and defeats but because of its triumphs (Beck, 2009: 6-8).

Beck gives us a Europocentric and West-centric world picture reminding us of a tendency prevailing within the Anglo-Saxon political tradition and English-speaking world in the mid-twentieth century. Namely, under the lap of political science as an empirical science, political (theory) was thought to be dead, to have nothing to offer, and deal with unnecessary

crisis as a positive entrepreneurial story, reminding us how some of the most popular (technological) companies like Airbnb, Uber, WhatsApp, or Pinterest, started as start-ups during the 2008 financial crisis (cf. Calvino et al., 2020; Stipančić, 2020).

${ }^{30}$ In his text "Welcome to western China!" Serge Halimi, editorial director of Le Monde Diplomatique notices this paradoxical pattern by the current French president Emmanuel Macron - as a constant critic of "illiberalism", he attempts to subordinate public liberties to the emergencies of the moment, endorsing "the rampant invasion of digital technology and the tracking of our private and professional lives, our exchanges and our political views" even more - the precautionary principle will have no limit encouraging "the replacement of human interaction with a tangled web of government sites, robots, voicemail, QR codes and apps" (Halimi, 2021). 
philosophizing and theorizing. Perhaps the most famous such voice was that of Peter Laslett (1956: vii), declaring the death of political theory. According to Beck, in the era of the victory of modernity, risk society resists the side-effects of modernization. Political conflicts are no longer based on class differences - over income, employment, social benefits, or, in general, ideological views of the world - but rather over the responsibility for managing world risks.

Therefore, as we are in the era of post-politics - Beck advocates the idea of reinventing politics through the concept of subpolitics: with the absence of traditional political conflicts and confrontations, politics has shifted (re-)appearing in different, new fields, thus differing from politics in a modern sense. As such, subpolitics allows actors outside the political or corporate system to appear on stage, not only social and political actors but also individuals. Thus, Beck indicates that politics is possible beyond the representative institutions of the nation-states, referring to the decoupling of politics from government and directing attention to indicators of global self-organization of non-state politics. In his words, subpolitics "means 'direct' politics - that is, selective intervention, sometimes even individual participation in political decisions, bypassing the instituons of representative will-formation (political parties, parliaments)", it means "the shaping and transformation of society from below" while "the state, business, science, law, the military, occupation, everyday existence, the private sphere in short, the basic institutions of first modernity - become caught up in the storms of global political controversies" (Beck, 2009: 95).

Thus, living in the age of post-politics also means the reduction of politics - politics is to be found in new fields of small life politics, as understood by Anthony Giddens in his book "Modernity and Self-Identity". Opposed to emancipatory practices as outdated, life politics concerns the individual issue of lifestyle; it is lifestyle politics including the policy of life decisions, whether it is about environmental, sexual, identity or other:

Life politics is the politics of a reflexively mobilised order - the system of late modernity - which, on an individual and collective level, has radically altered the existential parameters of social activity. It is a politics of self-actualisation ... Life politics concerns political issues which flow from processes of selfactualisation in post-traditional contexts, where globalising influences intrude deeply into the reflexive project of the self, and conversely where processes of self-realisation influence global strategies (Giddens, 2006: 214).

In January 2020, just two months before the global lockdown caused by the COVID-19 pandemic, the documentary "The Social Dilemma" dealing with the dangerous business models behind social networks premiered at the 2020 Sundance Film Festival and was released on Netflix. Big Tech is not only responsible for our data theft or election hacking; in the background, as the film claims, is the pervasiveness of technology - the intention to hack human psychology, design human behavior in a way that creates addiction, and the need for attention to the display. It is not only our digital data that is being sold but also the models of our behavior (what we read, what we watch, what we are looking for) in order for the algorithms to create content that would correspond to business models, equally adapting us to them. Our (digital) engagement and involvement are increasingly excluding and disengaging us (see: Hasanović and Adilović, 2021). We have moved from the age of 
information to the age of disinformation responsible for fake news, conspiracy theories, posttruth, and other catchy and attractive labels explaining our contemporality.

However, it would be too naïve and oversimplified to conclude how democracy is occupied and captured by social network algorithms, nor do social networks have their own goals. At one point, Ben, the main protagonist of the documentary played by Skyler Gisondo, is portrayed as a puppet - his movements and behavior were controlled by the algorithm. Yet, we do not see the ropes and the one who is holding and controlling them. That is precisely what is missing here. Hence, if we perceive the invisible ropes as the invisible power that lays beneath algorithms, what needs to be underlined is the fact that the digital virtual is not mere, self-contained reality but a reflection of the analogous material.

Describing his meetings with the Eurogroup, former Greek Finance Minister Yannis Varoufakis summarizes the democratic deficit in favor of the big business and financial market cartels descending from the European Union to the nation-states - a situation in which"MarioDraghi,the European Central Bank's president, would set the parameters within which we politicians had to labour with no recourse to any parliament or any process that might be thought of as democratic" (Varoufakis, 2017: 97-98).The depoliticization of the decision-making process also implies de-democratization, which is encouraged by undemocratic and unelected centers of power. In theory, we speak of democracy without people, or more commonly, of postdemocracy most representatively explained by Colin Crouch as an electoral game "managed by rival teams of professionals, experts in the techniques of persuasion and considering a small range of issues selected by those teams(...)politics is really shaped in private by interaction between elected governments and elites that overwhelmingly represent business interests" (Crouch, 2001: 2).

That is why Richard Seymour (2020) in his text "No, Social Media Isn't Destroying Civilization", later published on Jacobin, notices how the absence of capital from the documentary's imagination results in some strange formulations like that of artificial intelligence running the world. Superficial with explanations and arguments, the film functions as what it wants to criticize. It sells itself in a sensationalist way with its form, virality, and catchy content, teasing our psyche by giving us a fictional story, fragments of a techno-dystopian film. In other words, what is in the background is capitalism and capitalist, that is, market relations which not only allow information, behavior, or emotion to become a commodity but also transfer the analog anger of the masses betrayed by the mainstream political parties of the radical center to digital space. Hence, the time of populism, as authors like Chantal Mouffe (2018) or Ernesto Laclau (2018) would conclude, is an expression of resistance against the post-democratic and post-political state. Relating this on "The Social Dilemma" - "if YouTube and Facebook seem to promote far-right infotainment, that may say more about the societies in which the social industry profits than it does about the algorithms per se." (Seymour, 2020).

\section{Politizing the depolitized}

Relating this with the concept of life politics as subpolitics, it could be seen that the problem is not simply in bearing responsibility for individual life decisions but in what causes them. While in the first modern(ity), politics was as a technique of governing, the use-value 
of the administrative apparatus of the state, happening on the edges and alienated from the emancipatory questions of social reality, sub-politics is the:

[p]arodic subversion of the established regime - by reducing politics to micropolitics, it helps to maintain the status quo regimes of the realpolitik of the hegemonic reproduction of monocratic liberalism and the monopoly rule of the world of capital. Subpoliticaltactics is nothing else (...) but sanctioning the existing in the established politics (Zgodić, 2008: 214).

The COVID-19 pandemic pointed out how the decision-making process is given to technocratic and scientocratic elites, while the individual is thrown out of the political and left to himself in the domain of his own responsibilities - being "political" only about his own, personal life decisions. Closedness and quarantine expose how global self-isolation, the most perverse episode of ruthless individualism, has remained the only measure offered. More than ever before, in the circumstances like this, staying home meant the policy by which the individual is responsible for his destiny and health, a cry whose loudness conceals the systemic problem of market-oriented degradation of the commons, public health in particular. Hence, the measures that the governments have introduced to prevent the spreading of the COVID-19 - social distancing, lockdowns, quarantining, and curfews - collided with the "neoliberal capitalist part of the world's basic economic, political and ideological premises" (Vujanović, 2021). The recent market competition and geopolitics over the vaccines, together with their unavailability as a common good - being more a commercial product - confirmed this attitude even more (Ванковска, 2021), in which solidarity now means distance while freedom depends on security.

Furthermore, working from home illuminates the new coordinates of class relations - a new phase of global capitalism that stands behind the burnout and outsourcing of various immaterial workers. In the first volume of "Pandemic!", SlavojŽižek opposes claims such as those of Byung-Chul Han that we, as a society of imperatives, should have overcome the earlier stage of a society of control in which the effect maximization is the new form of subjectivization. ${ }^{31}$ The mutation of industrial capitalism into neoliberalism transformed workers into entrepreneurs, and work into immaterial in a way that today "everyone is an auto-exploiting labourer in his or her own enterprise" while the class struggle is being seen as "transformed into an inner struggle against oneself" (Han, 2017: 13). To some degree, only one group of workers fits Han's description - the army of precarious workers of the developed West - while, at the same time, ignoring the new geopolitics of exploitation - instead of replacing Fordist work with a collaborative way - outsourcing is at work: "work for Microsoft and Apple may be organized in a more cooperative fashion, but their final products are then put together in China or Indonesia in a very Fordist way - assembly line work is simply outsourced" (Žižek, 2020: 23).

Such class divisions acquired new significance in the pandemic, reminiscent of what was underlined by McKenzie Wark somewhat earlier in her book "Capital is Dead". The perhaps selfishly neglected fact is that although we depend on intangible and non-manual labor in the developed world, our components allowing us this convenience are still being produced in a

${ }^{31}$ Although Žižek refers to Han's bestseller "Burnout Society" published in 2015, the theses he criticizes are from the book "Psychopolitics: Neoliberalism and New Technologies of Power" from 2017. 
very Fordist manner and moved to the Far East. Similar, our clothes, shoes, or gadgets from Amazon, eBay, or some other platform someone has also to distribute to us (see Wark, 2019: 9-10). The accumulation of various oppressed groups whose marginalized status has been further exposed by the circumstances of the pandemic - not only workers in the broadest sense, but also women, racial, ethnic, religious, sexual, and other minorities such as people on the move or LGBTQ community - radiate nothing new except the toxic emission of inequality already present in our previously understood "normality". In other words, the so-called life politics, or subpolitics, are far from just policies of petty, individual decisions of individuals independent of major political and economic issues.

Nevertheless, the global quarantinization of society illuminates how the things we have so far predetermined understood as such may be thought differently, such as those depending by market logic can become a common, public good. Thus, perhaps most of all, digital spaces affirm new forms of the public good that goes beyond capital and marketdetermined logic. Right after the global lockdown, among numerous websites and apps that have appeared to make the everyday life of the "new normal" more natural were libraries and publishing houses. Offering free access to various books, magazines and literature, they pointed out a particular specialty of network platforms that is usually overlooked. Often characterized as a more immediate and democratic space concerning networking, production and distribution of content - its material aspect is being ignored, reducing the Network exclusively to its communicative segment (Hartley, 2012: 3). Instead of asking how to communicate, it is necessary to problematize the question of acting (PeovićVuković, 2016: 81) through their wider (un)accessibility and how the issue of ownership and the use of digital technologies, protocols and information would be understood as a social construction whose basis is inseparable from the material sphere of social relations. This is best seen in the commercialization of the internet and software industry as one of the most influential and profitable corporations globally on the one side, and a quiet but growing revolution in open source and free software (Kolman, 2014: 133-136) on the other side.

The idea of redistribution and demands for its fairness are becoming a sexy topic in the conditions of "new normality", though, for example, new forms of peer production, cooperation, and collective intelligence (Peters et al., 2020) - allowing the voices for socializing of the economy and economic democracy to become even louder. ${ }^{32}$ Without referring to some earlier works like those of Hardt and Negri (2009) or Erik Olin Wright (2010), I will here only take into account more recent works and ideas of, for instance, participatory socialism by Thomas Piketty (2020) or the book "People's Republic Walmart" in which the authors (Phillips and Rozworski 2019) expose the internal business logic of the largest global corporations of today - Amazon and Walmart - and it is that their economic model within the corporation is based on planned - and not market production, wondering whether the foundations of a new self-governing theory can be found in their practices..$^{33}$

\footnotetext{
${ }^{32}$ Wet, leftist dreams could even be echoed from the global financial centers such as the World Bank or IMF - appealing that the rich must bear the costs of the crisis through progressive taxation (SmithMeyer, 2020).

${ }^{33}$ It is the rhetorical question "How the World's Biggest Biggest Corporations Are Laying the Foundation for Socialism" which is asked in the very subheading of the book.
} 


\section{Towards 'the new': Feel like l've been here before ${ }^{34}$}

It is far from the truth that politics can only reappear as subpolitical phantasies of a global alliance of governments and activist's reactionary dealing with risks and individual issues of lifestyle, an egoist charge deprived of any broader social context being the new alliance between parliamentary and extra-parliamentary forces. In this manner, Beck will talk about (re)finding and reinventing the politics ${ }^{35}$ understanding it as "creative and self-creative politics which does not cultivate and renew old hostilities, nor draw and intensify the means of its power from them; instead, it designs and forges new content, forms and coalitions" (Beck, 2005: 136). Such an understanding of politics is beyond the right and left, West and East - it is the politics of reflexive modernization and the triumph of capitalism in which the aims of politics presuppose questions of responsibility, personal and individual decisions, and the side effects of successful modernization rather than political struggles and power relations and political institutions (state, parliaments, trade unions) within society that are thought to have been overcome.

Accepting the Europocentric universalism of Western, liberal democracies in which politics is perceived as a space of deliberation and compromise lacks the endeavor to demystify and overcome the causes of the risks being the "consequences of modernization and its achievements" while anticipating a different, changeable world instead of deliberation and compromise with the existing. Thus understood, Beck's and Ciddens's reductionism of the politics can be read as the praise of technocracy, its political and social consequences:

The dominance of technologists in political life makes politics and democracy, perceived in the technocratic ideological imagination, an unproductive and irrational practice of citizen participation in social and political processes (...) Technocracy changes and transforms political conflicts, which are necessarily produced by democracy, into conflicts that are resolved routinely: by technocratic interventions and professional administrative regulation (Zgodić, 2020: 27).

To set it up in a different way, not only is the absence ofdemos from the real political area already done through the post-democratic situation of neoliberal governments, but it also reduces the political potential of the demos to an individualized ${ }^{36}$ and reactionary civil society - the subpoliticization of society, as Beck $(2005,104)$ names it. Subpolitics seeks and strives for the negative concept of politics - to anticipate and prevent risks becoming catastrophes, while the positive aspect of politics - to create, remains beyond their reach.

${ }^{34}$ Chrous of Iron Maiden's "Deja vu“ from the "Somewhere in Time" album (1986).

35 Initially, in German, Beck's book was titled "Die Erfindung des Politischen" where the word (zu) erfinden can mean "invention", or "inventing", as well as "to find anew" as "reinventing", but - in English translation - not the political (das Politische) yet the politics.

${ }^{36}$ Beck, however, does not understand individualization in terms of atomization, isolation, loneliness or the end of any type of society nor disconnectedness, but, instead, it means "first, the disembedding of industrial-society ways of life and, second, the re-embedding of new ones, in which the individuals must produce, stage and cobble together their biographies themselves" (Beck, 2005: 95). Individualization is, simplified, reduced to the formula of 'do-it-yourself biography'. 
It is clear how subpolitics as reflexive (rule-altering) politics, in other words, can not be a substitute for politics in the classical, simple (rule-directed) sense of first modernity, nor the premature theses on its death and unsuitability no longer hold water. Indisputably, that what is being called subpolitics coexists with politics as well as one presupposes the other while their strong differentiation is increasingly disappearing considering their interpenetrating tendencies. More often, social movements - the subpolitized society - are growing into political movements and political parties, realizing the need to fight for their demands inside, and not just outside - or in parallel - from the formal and institutionalized political arena, as seen by numerous recent global (Podemos in Spain,Movimento 5 Stelle in Italy, Momentum in the UK...) as well as local examples (Ne Davimo Beograd in Serbia or Možemo! in Croatia).

The key problem here is the attempt for the ontological reduction of politics to a particular essence - the search for the essence of politics and the political, without accepting the possibility of subverting the foundationalist premises instead of accepting pluralities of contingent foundations, following the impossibility of a final ground. Politics does not end, nor can it end in eschatological finiteness - it is a constant process in which it is impossible to be "beyond power relations". It is precisely because of its evasion, as Chantal Mouffe notes, that makes the change impossible - in the post-political, political competition and democratic discussion are being disabled and disturbed. Hence, anticipating the "political difference" between politics (die Politic, la politique) and the political (das Politische, le politique), which occurs in the panoramic view of different authors, Mouffe understands the political as the ontological dimension of the ontical notion of politics as "the dimension of antagonism which I take to be constitutive of human societies, while by 'politics' I mean the set of practices and institutions through which an order is created, organizing human coexistence in the context of conflictual provided by the political" (Mouffe, 2005: 9).

As Oliver Marchant states - politics has to accept the fact that it is an open-ended process with neither a clear beginning nor a determined end or destination - since it does not take place in a vacuum but is always enfolded in sedimented layers of traditions - flexible and changeable (Marchant, 2017: 3). The ongoing global pandemic is just one episode in a series of crises that do not simply end so that a new one can emerge in the future. Crises occur and break simultaneously - absorbing existing and producing new, unpredictable outcomes. In Ernst Bloch's words, the moment when the ground of our normality is shaking, we feel confused because we do not know what is happening and why, emphasizing that in such moments the state of anxiety easily becomes the state of fear, placing itself above hope thus blocking any emancipatory and transformative impulses striving for succeeding rather than impotence (Bloch, 1996: 3).

Therefore, linear understandings according to which - horizontally speaking - we go from one point to another are to reject. Instead, the dialectical flow of social, political, and economic relations in their inter-collisions will open up and create new cracks that can be, at the same time, crises and opportunities, as much as emancipatory and de-emancipatory. It should be unequivocal here - the COVID-19 pandemic is not a consequence of dominant, hegemonic power relations, nor is the capitalist mode of production its cause. Far from it. On the other hand, the challenges we are facing within the "new normal" and which are within it deepening more than in the pre-pandemic state - such as the rising populism, distrust in the government and the degradation of democracy in the broadest sense (fake news, 
racism, people on the move, violations of workers' and minorities' rights in general, favoring supervision and control) - surely are.

\section{Concluding remarks}

The so-called "new normality" does not sharply dissect a state to "before" and "after" - our gradual habituation to them allows us that the new normality is being produced simultaneously and transformed into "normality". Moreover, isn't that what we rushed to name as the "new normality" in fact the outcome of the previously domesticated normality whose consequences have now surfaced and through whose achievements the catastrophe of modernization is presently spread? Different responses - and certainly, outcomes to the pandemic indicate that we are all, perhaps, in the same boat but not sailing in the exact directions, spreading through various political and social terrains and geopolitical contexts. ${ }^{37}$ Escaping "beyond power relations", therefore, is not possible because power relations are omnipresent. In other words, the intention to escape from politics is political in itself - by the very fact that it thereby favors the existing and enables its reproduction. Politics should be able not only to respond, but also to create and think up new contents, not only and exclusively within the same matrices, as Beck understands it, but to question them, respond and transform them anticipating new possibilities and different concepts.

Politicizing the "new normality" does not mean whether - and which - subcultural elements of some 21st-century hippies will be the new subjects of emancipation - the real question is how to approach alternatives and what they would be. What if they are already there? Sometimes disruptive processes are immensely important - they do not lead to crises, but as disruptive processes of the status quo, they shake our ideological glasses allowing us to look at the social world and the code with which it is written. Our blindness when we look anew and the moment we bring ourselves to the brink of (self-)censorship is like a pop-up window that pops up in our daily lives, offering us two wrong choices - to accept or give up in spreading of the code. However, the real challenge to us would be to write a new, heretical code in a naive and innocent programming language in which all those bugs of the existing are being produced, functioning as open-source for further, agonistic, plural interventions that do not stop, but lasting and following the dynamics and plurality of social relations and needs.

${ }^{37}$ Referring to the widely discussed statements launched by Italian philosopher Giorgio Agamben in his text "The Invention of an Epidemic" written in February 2020, and the later ones - describing how the media and authorities spreading a state of panic provoking authentic state of exception to enforce biopolitical discipline in which the state of exception is becoming a normal paradigm for government (Agamben, 2020) - Marco D'Eramo shows how Agamben in both (drastically) wrong and (somewhat) right. Not only he reminds us to the fact Western, liberal democracies tent to present freedom as freedom of choice, in which "social control and domination can no longer appear to infringe of the subject's freedom" (Žižek, 2019: 43), thus the claim "that coronavirus is being exploited to strengthen mass-surveillance infrastructure is no secret" (D'Eramo, 2021: 24), but he also underlines that "it is not just control and surveillance; it is also exploitation and extraction ... The resinous damage that this epidemic threatens to inflict on capital explains politicians' reluctance to enforce isolation and quarantine" (Ibid.: 26). 


\section{References:}

1. Agamben, G., 2020. L'invenzione di un'epidemia. [Online]

Available at: https://www.quodlibet.it/giorgio-agamben-I-invenzione-di-un-epidemia [Accessed 0409 2021].

2. Bartlett, J., 2018. The People Vs Tech. London: Ebury Press.

3. Beck, U., 1992. Risk Society: Towards a New Modernity. London/New York: SAGE Publications Ltd.

4. Beck, U., 2005. The Reinvention of Politics: Rethinking Modernity in the Global Social Order. Cambridge: Polity Press.

5. Beck, U., 2009. World at Risk. Cambridge: Polity Press.

6. Beer, T., 2021. Report: American Billionaires Have Added More Than \$1 Trillion In Wealth During Pandemic. [Online]

Available at: https://www.forbes.com/sites/tommybeer/2021/01/26/report-american-billionaires-have-added-more-than-1-trillion-in-wealth-during-pandemic/[Accessed 3108 2021].

7. Bloch, E., 1996. The Principle of Hope, Volume One. Cambridge: MIT Press.

8. Boyle, Francis A. 2020, "SARS-cov-2 is a biological warfare weapon", Security Dialogues, 11(2).

9. Calvino, F., Criscuolo, C. \& Verlhac, R., 2020. Uber, Airbnb, WhatsApp all started during a crisis. Startups must be protected during Covid too. [Online]

Available at: https://theprint.in/features/uber-airbnb-whatsapp-all-started-duringa-crisis-startups-must-be-protected-during-covid-too/454448/ [Accessed 3108 2021].

10. CBBH, 2019. Depoziti građana iznose 12,89 milijardi KM. [Online] Available at: https:// www.cbbh.ba/press/ShowNews/1229?lang=hr[Accessed 3108 2021].

11. Crouch, C., 2004. Post-democracy. Cambridge: Polity Press.

12. D'Eramo, M., 2020. The Philosopher's Epidemic. New Left Review, Issue 122, pp. 2328.

13. Forić, S., 2020. Pa ovo više nije normalno!. [Online] Available at: https://www.oslobodjenje.ba/dosjei/teme/pa-ovo-vise-nije-normalno-558090 [Accessed 3008 2020].

14. Friedman, M., 2002. Capitalism and Freedom. Chicago/London: The University of Chicago Press.

15. Giddens, A., 2006. Modernity and Self-Identity: Self and Society in the Late Modern Age. Cambridge: Polity Press. 
16. Halimi, S., 2021. Welcome to western China!. [Online] Available at: https://mondediplo. com/2021/08/01edito [Accessed 1509 2021].

17. Han, B.-C., 2017. Pyschopolitics: Neoliberalism and New Technologies of Power. London: Verso.

18. Hardt, M. \& Negri, A., 2009. Commonwealth. Cambridge: Harvard University Press.

19. Hartley, J., 2012. Digital Futures for Cultural and Media Studies. Oxford: WileyBlackwell.

20. Hasanović, J. \& Adilović, E., 2021. The Double Life of Virtual: Emancipation as Immobilization in an Isolated Age in. In: Erçetin, Şefika Şule et al. (eds.) Chaos, Complexity and Leadership 2020. Cham: Springer, pp. 63-86.

21. Kolman, G., 2014. Kodiranje slobode:Etika i estetika hakovanja. Beograd: Fakultet za medije i komunikacije.

22. Laclau, E., 2018. On Populist Reason. London/New York: Verso.

23. Laslett, P., 1956. Philosophy, Politics and Society. Oxford: Basil Blackwell.

24. Marchant, 0., 2007. Post-Foundational Political Through:Political Difference in Nancy, Lefort, Badiou and Laclau. Edinbourgh: Edinbourgh University Press.

25. Mouffe, C., 2005. The Return of the Political. London: Verso.

26. Mouffe, C., 2018. For a Left Populism. London: Verso.

27. Peović Vuković, K., 2016. Marx u digitalnom dobu:Dijalektički materijalizam na vratima tehnologije. Zagreb: Durieux.

28. Peters, M. A., Besley, T., Jandrić, P. \& Zhu, X., 2020. Knowledge Socialism: The Rise of Peer Production: Collegiality, Collaboration, and Collective Intelligence. Singapore: Springer Singapore.

29. Peterson-Withorn, C., 2021. Nearly 500 People Became Billionaires During The Pandemic Year. [Online]

Available at: https://www.forbes.com/sites/chasewithorn/2021/04/06/nearly-500people-have-become-billionaires-during-the-pandemic-year/ [Accessed 3108 2021].

30. Phillips, L. \& Rozworski, M., 2019. People's Republic Walmart. London/New York: Verso.

31. Picchi, A., 2021. Billionaires got $54 \%$ richer during pandemic, sparking calls for "wealth tax". [Online]

Available at: https://www.cbsnews.com/news/billionaire-wealth-covid-pandemic-12trillion-jeff-bezos-wealth-tax/[Accessed 3108 2021].

32. Piketty, T., 2020. Capital and Ideology. Cambridge: Belknap Press. 
33. Seymour, R., 2020. No, Social Media Isn't Destroying Civilization. [0nline] Available at: https://www.jacobinmag.com/2020/09/the-social-dilemma-reviewmedia-documentary [Accessed 2508 2021].

34. Smith-Meyer, B., 2020. Tax the rich to reduce debt after recovery, IMF says. [Online] Available at: https://www.politico.eu/article/imf-tax-the-rich-to-reduce-debt-afterrecovery/ [Accessed 2010 2020].

35. Stipančić, F., 2020. Kriza može biti odlična prilika za poduzetničku ideju, a venture building pravi model za njezin razvoj. [Online] Available at: https://www.netokracija. com/venture-building-startup-scena-kriza-166992 [Accessed 3108 2021].

36. The White House, 2021. Remarks by President Biden in Address to a Joint Session of Congress. Online https://www.whitehouse.gov/briefing-room/speeches-remarks/2021/04/29/remarks-by-president-biden-in-address-to-a-joint-session-ofcongress/ [Accessed 3108 2021].

37. Varoufakis, Y., 2017. And The Weak Suffer What They Must?. London: Vintage.

38. Vujanović, A., 2021. The Collective Body of the Pandemic: From Whole to (Not) All. [Online] Available at: https://www.e-flux.com/journal/119/400150/the-collective-bodyof-the-pandemic-from-whole-to-not-all/ [Accessed 2409 2021].

39. Wark, M., 2019. Capital is Dead: Is This Something Worse?. London/New York: Verso.

40. Wright, E. 0., 2010. Envisioning Real Utopias. London: Verso.

41. Zgodić, E., 2008. Realpolitika i njeni protivnici. Tuzla/Tešanj: Nardona i univerzitetska biblioteka "Derviš Sušić"; Centar za kulturu i obrazovanje.

42. Zgodić, E., 2020. Naučnici i upravljanje državom: O scijentokratiji i scijentizaciij javnih politika (knjiga prva). Sarajevo: Slovo bosansko.

43. Zuboff, S., 2019. The Age of Survellance Capitalism: The Fight for a Human Future at the New Frontier of Power. London: Profile Books.

44. Žižek, S., 2019. Kao lopov usred bela dana: Moć u doba postčovečanstva. Beograd: Laguna.

45. Žižek, S., 2020. Pandemic! COVID-19 Shakes the World. New York/London: OR Books.

46. Ванковска, Б., 2021. Синергия между геополитикой и биополитикой: в центре внимания вакцины от COVID-19. Журнал Войросы ӣолиш̄олог̄uи, 6(70), pp. 18251832. 